MALLOMO: Journal of Community Service

https://jurnal.umsrappang.ac.id/mallomo/index

Vol 1, No 2, Juni 2021, pp 90-97

\title{
Pembinaan Organisasi dan Pembentukan Struktur BUMDes Carawali Kecamatan Watang Pulu Kabupaten Sidrap
}

\author{
Lukman $^{1}$, Erfina ${ }^{2}$ \\ 1,2 IImu Administrasi Publik, FISIP, Universitas Muhammadiyah Sidenreng Rappang \\ Email: lukmansirap75@gmail.com
}

\begin{abstract}
Basically, there have been a lot of empowerment programs carried out by the Carawali village government. But unfortunately at the level of practice various deviations often occur due to various reasons. For example financial reasons, education and skills, health and so on. The company owned by the village of Carawali is one of the organizations that seems dull today. It is undeniable that the role of Village Owned Enterprises (BUMDes) is very large. Especially to overcome the social problems of society which can be a forum for developing human resources as well as being a forum for fulfilling and solving social problems in the midst of people's lives. The purpose of this service activity is to optimize the management of BUMDes Carawali. Therefore, in this service the authors carry out various strategies to activate the BUMDes Carawali organization which is currently not well managed. The strategies carried out are to carry out organizational mental development, foster administrative governance, and form structures through workshop activities. Thus this service can optimize the role of BUMDes Carawali in solving various problems in the community. The measure of the success of this activity is that the Carawali BUMDes can become healthy again with the formation of new administrators who can play a more public role in human resource development and assist the village government in solving existing social problems. With this BUMDes, the Carawali village government can reactivate its revolving fund.
\end{abstract}

Abstrak. Pada dasarnya sudah banyak sekali program pemberdayaan yang dilakukan oleh pemerintah desa Carawali. Namun sayang dalam tataran praktik berbagai penyimpangan 
acapkali terjadi yang disebabkan oleh beragam alasan. Misalnya alasan financial, pendidikan, dan keterampilan, kesehatan dan lain sebagainya. Badan usaha milik desa Carawali merupakan salah satu organisasi yang terkesan pakum hari ini. Tidak dapat dipungkiri peran organisasi Badan Usaha Milik Desa (BUMDes) sangat besar. Terutama untuk mengatasi permasalahan sosial masyarakat yang dapat menjadi wadah untuk melakukan pengembangan sumberdaya manusia disamping sebagai wadah pemenuhan dan pemecahan permasahalan sosial di tengah kehidupan masyarakat. Tujuan dari Kegiatan pengabdian ini adalah mengoptimalisasi pengelolaan BUMDes Carawali. Karenanya, dalam pengabdian ini penulis melakukan berbagai strategi guna mengaktifkan organisasi BUMDes Carawali yang saat ini tidak terkelola dengan baik. Adapun strategi yang dilakukan adalah melakukan pembinaan mental keorganisasian, pembinaan tata kelola administrasi, serta pembentukan struktur melalaui kegiatan workshop. Dengan demikian pengabdian ini dapat mengoptimalisasi peran BUMDes Carawali dalam penyelesaian berbagai permasalahan ditengah masyarakat. Adapun ukuran keberhasilan dari kegiatan ini adalah BUMDes Carawali dapat menjadi sehat kembali dengan terbentuknya pengurus baru yang dapat lebih berperan kemasyakat terhadap pembangunan SDM dan membantu pemerintah desa dalam memecahkan persoalan sosial yang ada. Dengan adanya BUMDes ini pemerintah desa Carawali dapat kembali mengaktifkan dana bergulirnya.

\section{Keywords:}

Organisation;

Structure;

BUMDes.
Coresponden author:

Email: lukmansirap75@gmail.com

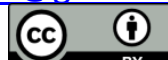

artikel dengan akses terbuka di bawah lisensi CC BY -4.0

Kata Kunci:

Organisasi,

struktur, BUMDes.

\section{PENDAHULUAN}

Sudah Menjadi Kewajiban kepada setiap Dosen di Perguruan Tinggi sebagaimana dijelaskan dalam Tridharma Perguruan Tinggi adalah Pendidikan, Penelitian, dan Pengabdian Masyarakat. Oleh karenanya sebagai salah bentuk kepedulian dan sekaligus wujud dari kegiatan pengabdian. Kami melakukan Kegiatan pembinaan dan pendampingan terhadap program pemberdayaan oleh pemerintah desa agar dapat berjalan secara optimal. Pada dasarnya sudah banyak sekali program pemberdayaan yang dilakukan oleh pemerintah desa Carawali termasuk kredit usaha kecil (Dana Bergulir), hingga pengelolaan hasil produksi yang sulit untuk dipasarkan. Dalam tataran praktik berbagai penyimpangan acapkali terjadi yang disebabkan oleh beragam alasan. Ketidak aktifan Badan Usaha Milik Desa (BUMDes) di Desa Carawali merupakan salah satu hal yang dapat menyebabkan berbagai permasalahan sosial tersebut tidak dapat diselesaikan. 


\section{2 | MALLOMO: Journal of Community Service}

Untuk mengurai masalah tersebut dirasa perlu diadakan pembinaan dan pemberdayaan masyarakat khususnya dalam pengelolaan organisasi BUMDes di desa Carawali. Pengabdian kepada masyarakat yang akan dilakukan mengambil tempat di desa Carawali Kecamatan Watang Pulu Kabupaten Sidrap.

Carawali merupakan sebuah desa mayoritas penduduknya terdiri atas kalangan masyarakat petani dengan sumber penghasilan tidak menentu. Desa Carawali merupakan salah satu desa dari 10 Desa/Kelurahan di wilayah Kec. Watang Pulu yang terletak 7 km dari ibukota kecamatan. Desa Carawali mempunyai luas wilayah 9,99 km persegi. Adapun batas-batas wilayah Desa Tanete, yaitu:

Sebelah utara : Kelurahan Benteng

Sebelah timur : Kelurahan Kadidi

Sebelah selatan : Desa Ciro-Ciroe

Sebelah barat : Manisa

Dalam kegiatan pemberdayaan ini, didapat sejumlah fakta tentang kondisi terakhir masyarakat desa Carawali, di antaranya adalah:

1. Masyarakat sering kesulitan memasarkan barang hasil produksinya, sehingga terjerat oleh rentenir dan bahkan tengkulak. Untuk peningkatan hasil produksi baik petanian maupun perkebunan masih sulit dilakukan, disebabkan masyarakat sering mengalami kelangkaan pupuk, bahkan sulit mendapatkan bibit benih yang berkualitas. Sedangkan BUMDes yang diharapkan dapat memenuhi kebutuhan Masyarakat belum mampu berjalan sesuai dengan harapan. Bahkan BUMDes desa Carawali Mengalami kebangkrutan pada tahun 2018.

2. Struktur kepengurusan BUMDes di desa Carawali sangat memprihatinkan Pengelolaan BUMDes desa Carawali tidak berjalan efektif disebabkan banyaknya pengurus yang tidak aktif.

3. Pembagian urusan bagi para pengurus dalam pengelolaan BUMDes masih belum jelas menyebabkan sering terjadinya miskomunikasi.

Dari data di atas, dapat disimpulkan bahwa BUMDes di Desa Carawali mempunyai masalah yang besar yaitu kemiskinan pengurus serta kemiskinan pengetahuan dalam mengelola organisasi. disamping pula keterampilan dalam melaksanakan tugas masing masing pengurus masih sangat rendah yang menyebakan seringnya BUMDes mengalami kesulitan dalam memperoleh dana awal bahkan pengelolaan bumdes di Desa Carawali pernah mengalami kebangkrutan.

Melihat situasi BUMDes yang demikian, program utama yang dilakukan dalam pengabdian ini adalah pelatihan keorganisasian bagi masyarakat dan pengurus BUMDes dan juga aparatur desa Carawali dengan menggunakan sarana dan prasarana desa yang ada. Program ini dirasa tepat karena pelatihan dibarengkan dengan BUMDes dapat memotivasi para aparatur dan juga masyarakat untuk membina wirausaha atau perkoprasian yang dapat menghasilkan pemasukan besar bagi masyarakat dan pemerintah desa sehingga PAD desa Carawali dapat ditingkatkan.

\section{Metode}

Dalam rangka mengubah kondisi BUMDes Carawali yang memiliki banyak pemasalahan ini, digunakan metode PAR (Participatory Action Research). Metode ini dilakukan untuk memahamkan masyarakat Carawali terhadap: a) kelemahan-kelemahan yang dialami dan dimilikinya, b) Keinginan-keinginan masyarakat untuk mengatasi kekurangan dan kelemahannya, c) menyusun strategi dan metode untuk memecahkan permasalahannya dan d) Membantu masyarakat mengatasi, memecahkan, dan menemukan jalan keluarnya.

Metode action research ini digunakan untuk tidak membuat masyarakat dampingan sebagai obyek, tetapi menjadikannya sebagai subyek pengabdian. Masyarakat sendiri yang memahami, menginginkan, dan memecahkan permasalahan yang melilitnya. Posisi tim pengabdian lebih sebagai fasilitator bagi masyarakat untuk mencapai cita-citanya dan memberikan jalan keluar dan merumuskan strategi yang dapat digunakan masyarakat untuk mencari jalan keluar bagi 
permasalahan mereka. Namun perumusan jalan keluar dan strategi ini tetap melibatkan masyarakat dengan harapan apabila masyarakat mengalami masalah-masalah sosial, mereka bisa memecahkan permasalahan mereka melalui BUMDes.

Dengan Participatory Action Research (PAR) ini bermanfaat untuk memfasilitasi dan memotivasi agar masyarakat khususnya Pengurus BUMDesuntuk mampu:

1. Mengidentifikasi kekuatan dan kelemahan Masyarakat serta problematikanya.

2. Menemukenali faktor penyebab problem Masyarakat dan alternatif solusinya

3. Menyusun strategi dan metode yang tepat untuk memecahkan permasalahan Masyarakat.

4. Menyusun rencana aksi berdasarkan prioritas, dan keberlanjutan program melalui tahapan-tahapan hingga mencapai target yang diharapkan.

Adapun strategi yang digunakan dalam melakukan action research ini adalah menggunakan metode yang dikemukakan oleh O'Brien (2001). Dalam proses penelitian action research ini ada empat tahapan dalam melakukan penelitian ini, yaitu:

1. Perencanaan (plan). Perencanaan ini dilakukan setelah memperhatikan kondisi riil di masyarakat dengan menggunakan analisis SWOT. Dalam menganalisis problematika di masyarakat dan menganalisis kekuatan, kelemahan, peluang, dan ancaman yang mungkin terjadi di masyarakat ini dilakukan dengan melibatkan masyarakat di Desa Carawali. Perencanaan ini meliputi strategi dan metode dalam memecahkan problematika yang dihadapi oleh masyarakat Carawali.

2. Tindakan (action). Setelah proses perencanaan dilakukan, Pengurus BUMDes desa Carawali mengimplementasikan rencana yang telah dibuat tersebut dengan dibantu dan difasilitasi oleh peneliti.

3. Pengamatan (observe). Pengamatan dilakukan untuk memperhatikan dan menganalisis keberhasilan, kelemahan, dan kekurangan strategi dan metode yang digunakan dalam menyelesaikan problematika yang terjadi di masyarakat.

4. Refleksi (reflect). Usaha-usaha yang telah dilakukan dalam memecahkan problematika di masyarakat Sumberpucung tersebut direfleksikan dan dievaluasi, baik kekurangan, kelemahan, dan keberhasilan strategi dan metode dalam memecahkan problematika masyarakat tersebut. Refleksi dan evaluasi ini berujung kepada perencanaan (plan) seperti pada poin pertama untuk menuntaskan problematika masyarakat, baik yang belum tuntas pada tahap pertama atau untuk memecahkan problematika yang baru hingga tercapai masyarakat Carawali yang Mandiri dan makmur.

Secara detail Kegiatan PKM ini menggunakan pendekatan bersifat persuasif edukatif dengan menggunakan metode ceramah, diskusi, dan praktek, melalui tahapan sebagai berikut:

1. Tim PKM melakukan survei lokasi pada bulan November 2020. Pendataan awal lokasi dan subyek dampingan. Fasilitator melakukan survei lapangan dan wawancara untuk mengetahui masalah yang dihadapi oleh masyarakat yang dipilih sebagai lokasi pengabdian, yakni masyarakat Carawali. Dari informasi yang terkumpul, peneliti menyimpulkan bahwa, di desa Carawali BUMDes tidak terkelola dengan baik. Oleh sebab itu, peneliti menfokuskan untuk mendesain program kegiatan yang dapat meningkatkan pengetahuan keorganisasian yang dapat meningkatkan keterampilan secara nyata utamanya kepada pengurus BUMDes desa Carawali

2. Tim PKM Koordinasi dengan toko Masyarakat, toko Pemuda, dan aparatur pemerintah desa untuk membina keorgansasian dan pengelolaan BUMDes agar dapat mencapai sasaran yang diinginkan.

3. Koordinasi dengan pemerintah Desa Carawali sebagai tempat pelaksanaan kegiatan mengenai teknis pelaksanaan kegiatan, tempat, fasilitas dan peserta.

4. Setelah pemerintah Desa Carawali memberikan kepastian waktu dan tempat pelaksanaan, tim PKM dibantu oleh mahasiswa Universitas Muhammadiyah Sidenreng Rappang mengundang masyarakat untuk menjadi peserta pelatihan dengan target peserta yang telah ditetapkan sebanyak 30 orang.

5. Pelaksanaan pelatihan dibuka oleh Kepala Desa Carawali dan ketua tim PKM.

6. Kegiatan pelatihan menggunakan metode ceramah untuk menumbuhkan motivasi peserta akan 


\section{4 | MALLOMO: Journal of Community Service}

pentingnya organisasi Bumdes sebagai organisasi yang akan memberi kontribusi terhadap PAD dan penanganan berbagai permaslahan sosial ditengah masyarakat. Selanjutnya dalam pelatihan ini dilakukan diskusi kepada peserta/masyarakat dengan tujuan melahirkan ide serta gagasan kreatifnya dengan melihat beragam potensi di Desa Carawali.

7. Pelaksanaan pelatihan dimana Para tokoh dan masyarakat dikumpul di kantor desa dan diajak untuk mengikuti kegiatan pelatihan keorganisasian, seperti pengenalan BUMDes dengan dasar hukumnya, sasaran, pengenalan visi dan misi BUMDes.

8. Pelaksanaan kegiatan Pelatihan keorganisasian yang di aula Kantor desa Carawali. Peserta yang diundang berjumlah 30 orang. Dalam kegiatan itu, pada sesi I, Tim memberikan materi tentang keorganisasian dan permasalahannya hingga tips untuk mengelola organisasi BUMDes yang baik. Kemudian, pada sesi II, Tim memberi motivasi untuk menjadi pengelola BUMDes yang memiliki tiga kunci kesuksesan yaitu pengetahuan, keterampilan, dan sikap pengelola dalam menjalankan organisasi BUMDes di desa Carawali.

9. Pembentukan struktur dan pengurus baru BUMDes di desa Carawali.

10. Melakukan koordinasi kepada kepala desa untuk segera melakukan pengukuhan pengurus BUMDesagar mereka dapat segera menyusun program.

11. Membagi kelompok para pengurus berdasarkan bidangnya masing- masing untuk menentukan programnya .

12. Melakukan pembinaan administrasi, seperti cara membuat proposal dalam rangka mendapatkan dana awal. Untuk menyukseskan kegiatan pengabdian ini, peneliti berencana menggandeng Universitas Muhammadiyah Sidenreng Rappang untuk memberikan fasilitas perlengkapan yang dibutuhkan sebagai desa binaannya.

\section{Hasil Dan Pembahasan}

Dari hasil wawancara ditemukan beberapa keluhan dari masyarakat dan salah satunya adalah pengelolaan BUMDes yang mengalami kemacetan. Bahkan menurut keterangan dari masyarakat bahwa pengurus BUMDes tidak ada yang aktif. Dari keterangan tersebut maka tim PKM menyusun langkah strategis untuk melakukan kegiatan pelatihan dengan menyusun jadwal dan tempat pelaksanaan lalu berkoordinasi dengan beberapa tokoh masyarakat dan pemerintah setempat di desa Carawali . Setelah mendapatkan persetujuan dari kepala desa Carawali maka TIM PKM mengundang beberapa tokoh masyarakat terutama tokoh pemuda untuk mengikuti kegiatan pelatihan keorganisasian. Adapun proses persiapan kegiatannya dimulai dari penyusunan konsep undangan oleh Tim PKM sebagaimana terlihat pada gambar 2.1 berikut: 


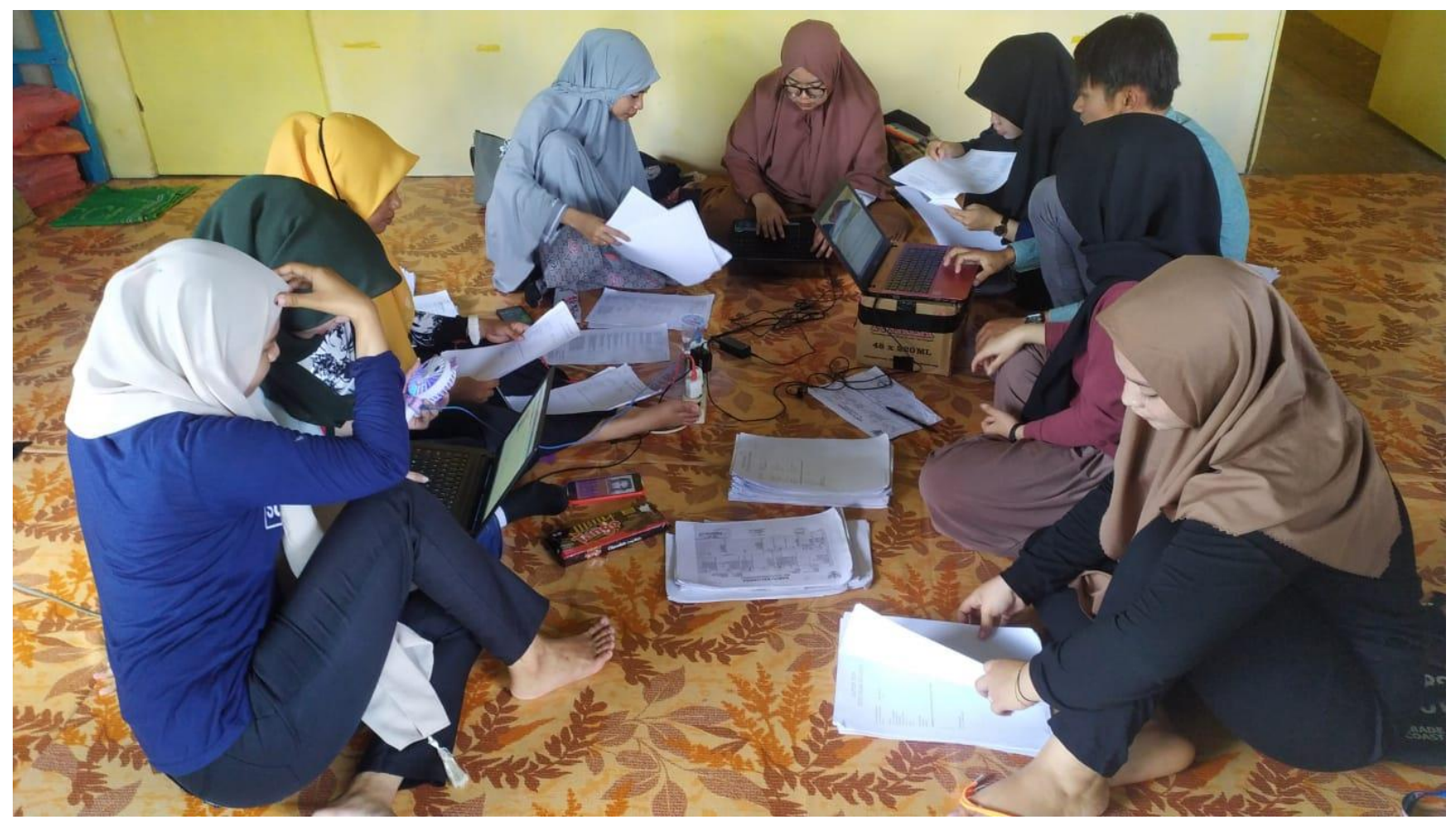

Gambar 1. Penyusunan undangan

Persiapan surat undangan kepada masyakat untuk mengikuti kegiatan pelatihan keorganisasian di kantor Desa Carawali. Hal ini untuk mengembangkan Pengetahuan dan keterampilan khusus, seperti, bagaimana memulai, bagaimana melakukan perekrutan, bagaimana mengelola organisasi BUMDes, bagaimana mendapatkan modal oleh pengurus BUMDes desa Carawali belum dipahami. Dari beberapa Masyarakat yang tidak melibatkan diri pada kegiatan tersebut, salah satu penyebabnya karena tidak memiliki keterampilan dalam mengelola administrasi dan juga kemampuan untuk berkomunikasi dengan orang lain.

Melihat kenyataan Masyarakat yang masih kurang memahami bagaimana mengelola organisasi dan keterampilan dalam menjalankan administrasi BUMDes di desa Carawali. sebagai salah satu desa binaan Universitas Muhammadiyah Sidenreng Rappang di Kabupaten Sidrap. Sedangkan mereka tidak sanggup untuk mengikuti pendidikan karena tidak memiliki biaya dan waktu yang cukup, maka di desa Carawali perlu ada pelatihan keorganisasian, dan sekaligus pembentukan struktur serta pembagian tugas masing-masing pengurus agar pengelolaan BUMDes dapat berjalan lancar. Dengan adanya Pelatihan keorganisasian dan strukturisasi organisasi untuk membantu Masyarakat dalam mengelola BUMDes yang tidak bisa terkelola dengan baik selain untuk pemenuhan kebutuhan masyarakat dan juga diharapkan mereka dapat menambah penghasilan asli daerah di desa Carawali.

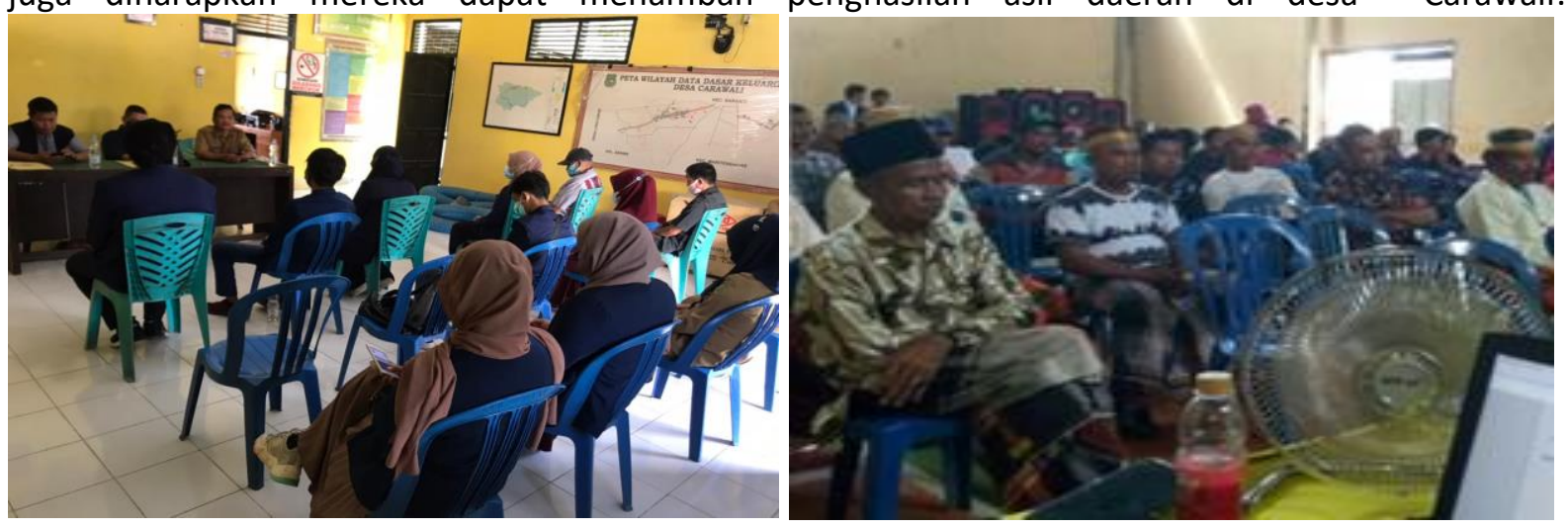

Gambar 2 Suasana pelatihan keorganisasian dan kepemimpinan BUMDes

Kegiatan ini melibatkan beberapa Masyarakat yang berada di desa Carawali bertujuan untuk meningkatkan semangat mereka untuk mengelola BUMDes. Pengurus BUMDes adalah calon penerus bangsa di masa depan. Oleh sebab itu, membina BUMDes, merupakan tantangan yang harus dilakukan 
demi pembangunan dan kemakmuran masyarakat Carawali di masa yang akan datang. Selanjutnya setelah dilakukan pelatihan keorganisasian maka tim PKM langsung melakukan pembentukuan Pengurus BUMDes yang baru. Berkat dukungan dari pemerintah desa dan para tokoh masyarakat maka akhirnya terbentuk pula pengurus bumdes yang baru lalu kemudian di kukuhkan oleh kepala Desa Carawali.

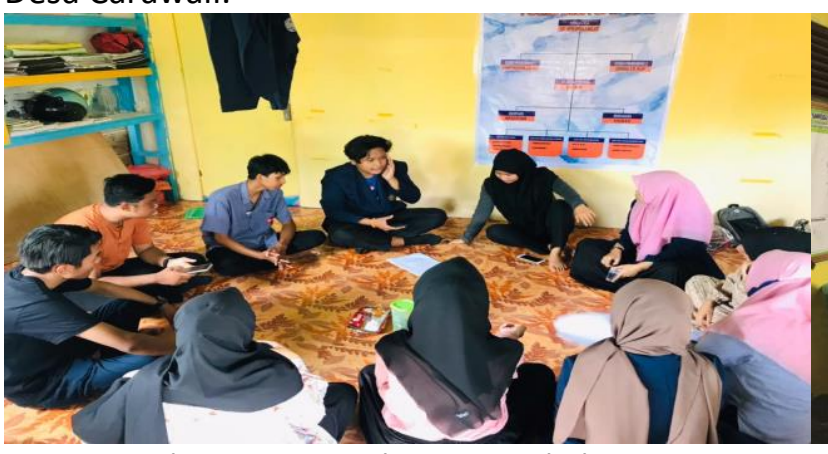

Gambar 3. Suasana breaping sebelum pembentukan pengurus baru

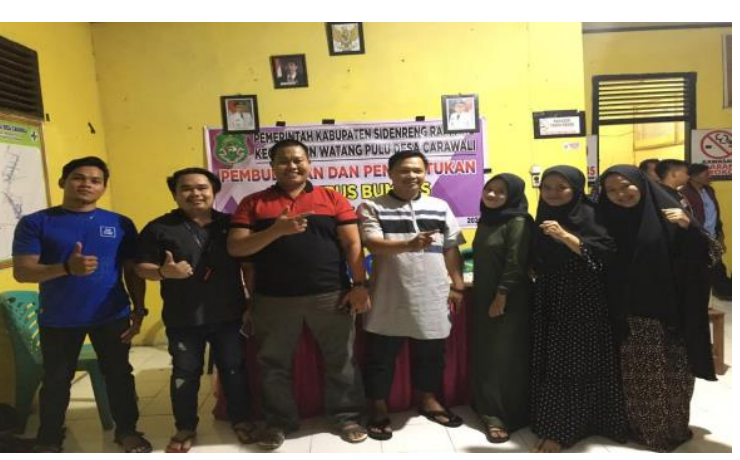

Gambar 4. Suasana pengukuhan pembentukan pengurus Bumdes desa carawali

\section{Bantuan peralatan yang digunakan:}

dalam kegiatan ini kami menggunakan beberapa bahan antara lain: laptop, alat pendataaan, dan Handphone, LCD. Adapun indikator keberhasilan kegiatan ini adalah tersselenggaranya pelatihan Pengorganisasian BUMDes dengan lancar sesuai dengan yang direncanakan disamping juga terbentuknya pengurus baru BUMDes Desa Carawali. Keberlanjutan program yaitu: dengan terbentuknya pengurus baru BUMDes desa Carawali diharapkan dana bergulir yang terkesan macet di tengah masyarakat dapat kembali di kelola disamping juga berbagai program yang lainnya. Adapun hambatan yang dihadapi dalam kegiatan pembinaan organisasi dan pembentukan BUMDes ini adalah keberadaan masyarakat diwaktu siang sangat sulit untuk ditemui sehingga untuk menemui mereka sangat sulit.

\section{Simpulan}

Pelaksanaaan Pengabdian ini mendapat sambutan positif dari Aparat Desa dan masyarakat dengan turut aktif dalam membantu proses perekrutan. kegiatan ini memberikan motivasi tersendiri kepada masyarakat untuk belajar dan mengenal banyak bentuk bentuk pengelolaan organisasi lebih utamanya BUMDes. Hal ini akan menjadi modal baik bagi pengurus untuk membawa BUMDes Carawali menuju organisasi yang sehat dan menjadikan desa Carawali sebagai desa mandiri.

Berdasarkan hasil kegiatan ini diharapkan tetap ada monitoring dan pembinaan berkelanjutan terhadap implementasi kegiatan Keorganisasian dan Restrukturisasi BUMDes di Desa Carawali ini, sehingga output kegiatan tetap dapat memberikan nilai tambah kepada masyarakat Desa Carawali serta terjalin sinergitas dengan bentuk program pengabdian Dosen Universitas Muhammadiyah Sidenreng Rappang yang lain dan sudah berjalan.

\section{Daftar Rujukan}

Anggraeni, M. R. R. S. (2017). Peranan Badan Usaha Milik Desa (Bumdes) Pada Kesejahteraan Masyarakat Pedesaan Studi Pada Bumdes Di Gunung Kidul, Yogyakarta.

Agunggunanto, E. Y., Arianti, F., Kushartono, E. W., \& Darwanto, D. (2016). Pengembangan desa mandiri melalui pengelolaan badan usaha milik desa (BUMDes). Jurnal Dinamika Ekonomi \& Bisnis, 13(1). 
Dewi, A. S. K. (2014). Peranan Badan Usaha Milik Desa (BUMDes) Sebagai Upaya Dalam Meningkatkan Pendapatan Asli Desa (PADes) Serta Menumbuhkan Perekonomian Desa. Journal of Rural and Development, 5(1).

Nurhayati, C. (Ed.). (2018). BUMDes dan kesejahteraan masyarakat desa. Pusat Penelitian, Badan Keahlian, DPR RI, Bidang Kesejahteraan Sosial.

Panduan Pengabdian Masyarakat UMS Rappang 2019

Ramadana, C. B. (2013). Keberadaan Badan Usaha Milik Desa (BUMDES) sebagai Penguatan Ekonomi Desa. Jurnal administrasi publik, 1(6), 1068-1076.

Suleman, A. R., Revida, E., Soetijono, I. K., Siregar, R. T., Syofyan, S., Hasibuan, A. F. H., ... \& Syafii, A. (2020). BUMDES Menuju Optimalisasi Ekonomi Desa. Yayasan Kita Menulis.

Sudianta, S. P. D., \& HADY, I. G. P. I. (2019). Sistem Informasi Pengelolaan Simpan Pinjam Bumdes Banjarasem Berbasis Web. 